and borrow many examples from this book in my own future discussions.

Finally, his treatment of religion and childhood is, I believe, precisely accurate. We do our children a great disservice (which Dawkins goes so far as to call abuse) by forcing religion upon them at an age where they are far too young to digest the deep and subtle issues associated with the possibility of divine purpose. In doing so, we encourage them to rely on potentially destructive emotions rather than to use their brains. And pondering how to build a world of adults that might result from the latter rather than the former is surely what motivates Dawkins here, even if his approach might also provoke some religious fundamentalists to harden their unfortunate belief that knowledge and reason are dangerous things, to be avoided at all costs.

Lawrence M. Krauss is Ambrose Swasey Professor, and director of the Center for Education and Research in Cosmology and Astrophysics, at Case Western Reserve University, 10900 Euclid Avenue, Cleveland, Ohio 44106-7079, USA. His most recent book is Hiding in the Mirror.

\title{
The hero of Gombe
}

\section{Jane Goodall: The Woman Who Redefined Man \\ by Dale Peterson \\ Houghton Mifflin: 2006.672 pp. \$35}

\section{W. C. McGrew}

In this age of hyperbolic subtitles - such as Frans de Waal's Our Inner Ape: A Leading Primatologist Explains Why We Are Who We Are (Riverhead, 2005), or Richard Dawkins: How a Scientist Changed the Way We Think (Oxford University Press, 2006) - comes another with a major claim. Dale Peterson has produced the long-awaited, definitive biography of (arguably) the world's leading figure in primatology.

$\mathrm{He}$ is surely well qualified to do so, not only as an award-winning author, but also as the editor of two previously published volumes of Goodall's letters, as well as the co-author with her of an influential book that crossed disciplinary lines (Visions of Caliban, Houghton Mifflin, 1993). But might he be too close to his subject to be able to give us an objective account? Might his ambitious subtitle be exaggerated? Happily, the answer to both questions is no.

Goodall is first and foremost associated with wild chimpanzees - more particularly, with one small population of these African apes living on the eastern shores of Lake Tanganyika, in western Tanzania. Her study of the chimpanzees of Gombe, begun in 1960, continues to this day, and has spawned many books, films and articles, both scientific and popular. Indeed, our view of that species, which (along with the bonobo) is humanity's nearest living relation, was shaped, at least in the West, by Goodall's early researches, as reported widely by the National Geographical Society. Few of us have not seen the evocative images of the slim, pony-tailed young woman and her hairy subjects in the Edenic surroundings of Gombe.

But what of the subtitle's claim, that she has redefined our species, Homo sapiens? This originates in the response of Louis Leakey, the flamboyant archaeologist and mentor of Goodall, to her unexpected finding that the apes not only used tools but also made them, as part of their extractive foraging. He stated, with characteristic panache, that now we must redefine 'tool', redefine 'man', or accept chimpanzees as humans. This blurring of longestablished boundaries was further advanced by Goodall's observations of chimpanzees doing other human-like things, such as hunting, cannibalism, warfare, adoption and ritual-like displays.

The book is comprehensive, following Goodall from her childhood interest in animals through her somewhat chequered young adulthood as debutante and waitress. The breakthrough came with a self-financed trip to Kenya, where she met Leakey, who set her on the route to primatology, although she had no prior training nor higher education. Her . aptitude showed quickly as she met chimpanzees on her first day in the field and discovered tool use and meat eating within the first few months. These successes led to her acceptance at the University of Cambridge, UK, to do a doctorate in ethology, despite nothaving a first degree. From that point onwards, she never looked back.

Peterson writes vividly. Descriptions of early days at Gombe, based on excerpts from Goodall's field notes and letters home, come alive. Days in the forest or on the savanna capture the downs (ill health, frustrations with sparse resources) as well as the ups (discovery of totally new phenomena, fast friendships) of field work. Key incidents, such as the Gombe kidnapping, in which four students were held for ransom by Congolese rebels, are revealing; for instance, for weeks in captivity, they had but one English-language book, Niko Tinbergen's The Herring Gull's World (Collins, 1953).

Heroes and villains abound. A series of older male mentors, such as Robert Hinde at Cambridge and David Hamburg at Stanford University, California, were instrumental in guiding the neophyte Goodall. Others were less helpful, such as the zoologist Solly Zuckerman, who, in chairing the symposium at which Goodall first presented her results, dismissed them as fantasy. Lesser egos would have been crushed. The National Geographic Society was both saviour and censor, providing vital funding in the early days, but repeatedly restricting her efforts to present her findings. Easily the most influential figure, however, was Leakey, who although crucial to Goodall's emergence, also complicated her life on personal and professional fronts. Having offered her the Gombe project, he then offered it to another attractive young woman, and kept Goodall waiting for months, until the other turned it down.

Peterson gives the reader useful endnotes but a limited list of references: this is not the place to learn about primatology. The photographs are disappointing, all being in black and white, and mostly snapshots.

The book could have been called 'The Many Lives of Jane Goodall', given her several career transitions: from chimpanzee expert, to distinguished scientist, to committed conservationist, to animal-welfare activist, to global campaigner for the environment, to eminent 'world citizen' in the causes of youth and peace. She would be famous for any of these incarnations, although Peterson is a bit over the top in terming her the most visible scientist of the twentieth century (cf. A. Einstein) and the best-known female scientist in history (cf. M. Curie). Regardless of this, Peterson's volume is the one for which Goodall's devotees have been waiting, and it will deservedly enjoy much success.

W. C. McGrew is at the Leverhulme Centre for Human Evolutionary Studies, Department of Biological Anthropology, University of Cambridge, Cambridge CB2 3DZ, UK. 